\title{
Ambigüedad de la imagen: la dimensión pulsional en El diablo en el ojo de Jesús Gardea ${ }^{1}$
}

\author{
Ambiguity of the Image: the Drive Dimension \\ in El diablo en el ojo by Jesús Gardea
}

\author{
DANiel SAMPERIO JimÉneZ \\ Universidad Autónoma Metropolitana-Azcapotzalco \\ danielsamjim@gmail.com
}

Resumen: Conforme Jesús Gardea fue desarrollando su narrativa, la imagen poética se convirtió en uno de sus principales recursos estilísticos como en la novela El diablo en el ojo (1989). Su impronta en la narración revela una zona de ambigüedad tras la que asoma una dimensión de pulsiones en la historia. Este artículo analiza cómo se expresa estilísticamente esta dimensión en dos pasajes iniciales de la novela, entendida desde las nociones de Freud (pulsiones de vida y muerte), con el objetivo de indagar en el carácter ambiguo de la imagen y la visión de mundo que proyecta. Antes de ello, se repara en la complejidad del lenguaje y modo de narrar por medio de imágenes (desarrollo metafórico) de Gardea a partir de una revisión necesaria de su concepción de la escritura.

\author{
Palabras Clave: \\ Jesús Gardea; \\ imagen poética; \\ desarrollo metafórico; \\ pulsión; \\ psicoanálisis; \\ estilística.
} KEYWORDS: His handiwork in the narrative reveals a zone of amJesús Gardea; biguity from which emerges a dimension of driving Poetic image; forces in history. This article analyzes how this dimenMetaphorical sion is stylistically expressed in two initial passages development; of the novel, understood from the notions of Freud Drive; (life and death impulses), with the aim of investigating Psychoanalysis; the ambiguous character of the image and the world Stylistics. vision that is projected. Prior to this, the complexity

1 Este artículo forma parte de una investigación en torno al proyecto "Imagen e iconoclasia en la obra de Jesús Gardea". Beca Conacyt Estancias Posdoctorales Nacionales 2017. Clave 917051. 
of the language and the way of narrating through images (metaphorical development) of Gardea is examined based on a necessary review of his conception of writing.

recepción: 01 febrero 2018

aceptación: 11 abril 2018

Jesús Gardea (1939-2000) alcanzó uno de los momentos más logrados de su mundo ficcional con la publicación de El diablo en el ojo en $1989 .{ }^{2}$ El autor venía desarrollando una narrativa en torno al pueblo ficticio de Placeres, situado en medio del Ilano, azotado por un clima extremoso, poblado por hombres de trato parco, rijosos y solos, hondamente perceptivos a los matices sensoriales del ambiente. Estos elementos aparecieron de nuevo en esta obra, aunque en consonancia con una visión de mundo más acabada. ${ }^{3}$ En efecto, en El diablo en el ojo se incorporó a la historia de un ajuste de cuentas, tan característica de Gardea, una concepción de Placeres como irónico trasunto del infierno. En este espacio de dimensiones simbólicas, se narra en esencia una confrontación de fuerzas entre la oscuridad y la luz. El título de la novela es un reflejo puntual de esta dicotomía: por una parte, "el diablo" alude al mundo degradado y abandonado al Mal de la historia mientras, por otra, "el ojo" lo hace al sentido espiritualizado que trata de encontrar una experiencia liberadora en medio de ese mundo. La forma en que ambos términos aparecen implicados en el título es aún más reveladora de cómo ocurre esa lucha de fuerzas. Éstas, de hecho, aparecen personificadas e identificadas con tales términos: "el diablo" es encarnado en el personaje de Borja, mientras "el ojo" remite al narrador intradiegético de la novela.

\footnotetext{
${ }^{2}$ Dentro de su novelística, esta obra se sitúa entre las novelas anteriores $E /$ sol que estás mirando (1981), La canción de las mulas muertas (1981), El tornavoz (1983), Soñar la guerra (1984), Los músicos y el fuego (1985), Sóbol (1985), y las posteriores El agua de las esferas (1992), La ventana hundida (1992), El árbol cuando se apague (1997), Juegan los comensales (1998), El biombo y los frutos (2001) y Tropa de sombras (2003).

${ }^{3} \mathrm{Sin}$ duda en El diablo en el ojo, Gardea explotó la riqueza y complejidad del mundo de Placeres. Tan es así que, con esta novela, pareció agotar ese mundo ficcional. Se puede comprobar que en la siguiente novela, El agua de las esferas, ya no aludió a Placeres, aunque recreaba un ambiente similar, mientras en las demás que siguieron lo abandonó para desarrollar las historias en espacios cerrados.
} 
La presencia del "ojo" en tanto narrador es fundamental. En líneas generales, este narrador busca vengarse de Borja por haberlo dejado tuerto (se entiende por qué se refiere a sí mismo como "el ojo"), quien además ha cometido otras atrocidades que se van conociendo en el transcurso de la novela. El narrador teje la historia de esta venganza con episodios que dan cuenta de la brutalidad de Borja y sus hombres, y de su propia iniciativa para eliminarlo. Pero la trama nunca es tan nítida; hay que irla adivinando. Al contrario, se trata de una serie de hechos que van tomando forma a partir de un ejercicio narrativo de asociaciones, intuiciones, casi presentimientos.

Esta manera tan particular de narrar de Gardea en El diablo en el ojo vino acompañada de una voluntad estilística, que fue trabajando especialmente con mayor empeño a partir de Los músicos y el fuego. ${ }^{4}$ Esta voluntad se basa en una utilización recurrente de la elipsis, la dislocación sintáctica y la imagen poética. El empleo cada vez mayor de estos recursos ocasionó, naturalmente, la puesta en crisis de una forma convencional de narrar y, en cambio, el desarrollo de una narrativa que está más cerca de la poesía. Esto llevó a que sus historias estuvieran marcadas por la ambigüedad y lo inaprehensible como en El diablo en el ojo, cuya visión de mundo es de una enorme complejidad. Entre lo que más Ilama la atención de esta novela está la dimensión pulsional de la historia, la cual se advierte tras una narración que principalmente aglutina imágenes poéticas. Antes de entrar en su análisis, conviene considerar el talante del lenguaje enrevesado de Gardea y la particular concepción de la escritura que lo motiva con los problemas que conlleva. Hay un carácter francamente aproximativo en la escritura de Gardea que delinea un lenguaje de imágenes y una forma de narrar excepcionales en El diablo en el ojo, los cuales apuntan a una honda dimensión pulsional que caracteriza su visión de mundo. Ésta difícilmente podría afincarse con toda su complejidad sin el recurso de la imagen y su naturaleza ambigua.

\footnotetext{
${ }^{4}$ Tal voluntad de estilo tiene como antecedente el cuento "Fuga mayor" de Los viernes de Lautaro (1979) y el único libro de poemas que publicó, Canciones para una sola cuerda (1982).
} 


\section{Escritura y aproximación}

Para valorar con justa magnitud la narrativa de Jesús Gardea posterior a Los músicos y el fuego y el trabajo con la imagen en El diablo en el ojo, es necesario tener muy presente cómo concebía la escritura. El autor dejó dispersas, en entrevistas y en un texto ensayístico, ${ }^{5}$ algunas reflexiones sobre su trabajo como escritor. Se trata de una reflexión de muchos años, en los que no hubo cambios significativos, sino en que más bien el autor fue profundizando en algunos aspectos de la escritura. Éstos desde un inicio despertaron su interés y se fueron clarificando con la voluntad de estilo presente en cada obra. De modo que para comprender un lenguaje como el de El diablo en el ojo vale acudir incluso a reflexiones posteriores, pues están en el orden de una misma concepción escritural y se derivan de la práctica. Recurrentemente, Gardea afirmaba que cada vez que emprendía una novela o un cuento, no partía de un esbozo o un tema que, a la larga, le sirviera para estructurar la historia:

Hasta ahora, nunca he usado esquemas para escribir. Vagas ideas sí, que luego, andando la escritura, se van a la porra. No todas, desde luego. Creo que el argumento, o como quiera que se llame eso, me va saliendo. Yo, como los franceses de la Intervención —nos decía un maestro allá en los días de la secundaria— no soy dueño más que del terreno que piso. Lo demás es oscuridad, o casi. En tales condiciones ¿qué esquema va a haber? (2000: 64).

En este sentido, pertenecía a ese tipo de escritores que no se "imponen" sobre el texto sino al contrario, como en las escrituras de Juan Rulfo, José María Arguedas o Juan Carlos Onetti: "Recuerdo que Onetti decía que él no escogía los temas, los temas se le imponían. Así sucede conmigo, no por afán de compararme con Onetti, pero la verdad es que es una compulsión, incluso el tema, la mayoría de las veces no lo tengo" (1994a: 5). Con partir de una palabra o de una frase, Gardea no estaba buscando, precisamente, hacer funcionar el texto en términos de argumento, pero sî de lenguaje, de igual manera en que un poeta (no tanto un narrador) traba-

5 "La palabra es el cuento". Texto presentado en el marco del Encuentro de Narradores Edmundo Valadés sobre Teoría y Práctica del Cuento realizado en Tuxtla Gutiérrez, Chiapas, en 1984; véase Gardea 2008. 
jaría la palabra. Esto daría a la larga una estructura como resultado, sin que su punto de arranque tuviera que sujetarse a una pensada de antemano. Es como si la escritura de Gardea contradijera el principio de causalidad que presupone Poe en "La filosofía de la composición", pues si para éste antes de escribir es necesario tener presente una estructura y el desenlace de la historia, aquél comienza escribiendo sin tenerlos muy en claro. Hay un par de sugerentes símiles con los que Gardea se refería a su trabajo de escritura y que expresan esas cualidades. Por un lado, decía que trataba de cascar las palabras "como se cascan las nueces, rompiéndolas, para ver qué tienen adentro" (1989b: 20). Por otro, afirmaba que "para mí escribir es como excavar un hoyo a ver qué encuentro" (1993a: 57).

El autor reservaba momentos de gran dedicación a la escritura. Pasaba cerca de tres horas diarias ocupado en este quehacer, pero al final escribía realmente poco: "A veces corro con suerte y a lo mejor terminaré una cuartilla. Aunque casi nunca he hecho una cuartilla de una sentada, casi nunca. Lo que hago son medias cuartillas o menos" (1995: 67). Para un escritor disciplinado, se entiende un poco el porqué si se asoma a sus hábitos de escritura:

Trabajo en máquina mecánica y escribo con dos deditos, borro y corrijo mucho. Uso papel grueso para que resista tantos borrones sobre la máquina y me vuelo líneas enteras. Soy muy drástico cuando considero que algo es insalvable. Escribo muy despacio porque busco ser lo más preciso posible. A veces me he tardado dos horas en hacer un renglón y no escribo más allá de tres horas al día, no podría aguantar más. Ése ha sido mi ritmo de trabajo durante años (1993a: 57).

Pero no sólo se tardaba por corregir continuamente sobre el papel, sino también porque la corrección ocurría muchas veces, incluso, antes del momento de escribir. Había largos periodos de silencio y concentración antes de empujar las primeras teclas de la palabra o la frase que ya habían depurado el oído y la intuición. La actitud de Gardea frente a la escritura siempre aparece rodeada por un halo de misterio. Su escritura describe una aproximación a algo que apenas se insinúa. En este sentido, es sugerente la idea que Gardea tenía de la escritura como un lenguaje de resonancias: "Una palabra que tiene un verdadero tono, inevitablemente 
va a resonar en otras palabras no dichas, que están en ti o en tu mundo. Una palabra dicha con precisión tiene que resonar con otras que le son familiares, y sin esa resonancia la palabra no tiene sentido, no tiene tono, suena falsa" (1993b: 63). Concebía su trabajo como una labor paciente que esperaría dar con la resonancia de una palabra que detonaría la presencia de otras tantas.

Se trata de una concepción de escritura que empujó al autor a concentrar, progresivamente, un número mayor de procedimientos estilísticos y que legó un lenguaje cada vez más enigmático a tal punto que la última experiencia narrativa de Gardea roza lo incomprensible. De modo que lo invisible, lo inabarcable y lo oculto parecieron ser sugeridos con más fuerza en su obra. Vicente Francisco Torres, amplio conocedor de este autor desde sus primeros libros, aventuró al respecto la idea de que "Gardea pretendía transmitir algo del misticismo en que se envolvía durante las tres horas diarias que se dedicaba a la escritura" (156). Sin duda, las implicaciones de esta concepción escritural son un asunto complejo. Los largos periodos de silencio y quietud que precedían la escritura en Gardea para empujar las primeras letras podrían entenderse como un acto de recogimiento, en el más puro sentido de los lenguajes de la mística y la ascética:

Hay que regresar a lo ilimitado, lo silencioso por impronunciable, para saber que este silencio imponderable es también la Palabra misma que nos pondera. Hay que regresar a nosotros mismos, a la quietud silenciosa de nosotros mismos, para oír el verdadero decir de la palabra: su decir anunciado, pronunciado y callado. Allí lo que san Juan Ilamó la soledad sonora; lo que san Juan llamó la música callada (Xirau 1968: 121). ${ }^{6}$

Es cierto que el autor incluso alude, en entrevistas, al Ilamado de una voz y al sometimiento:

Yo siempre he pensado que a mí no me llama el inconsciente, a mí me llama el "supraconsciente", por decirlo así: otro mundo, otra verdad, que no está aquí dentro; no estas locuras freudianas de que el inconsciente habla por el escritor. No: si es vocación de vocare, si es un llamado, ¿qué caso tendría que fuese un llamado desde mí mismo? Tiene que ser un llamado desde fuera. Incluso así

${ }^{6}$ Para una reflexión más actual y abundante bibliografía, véase Andrés 2010. 
la literatura puede librarse de un horizonte totalmente literario, entonces tiene otra finalidad. No sé cuál, pero tiene otra que no es exclusivamente literaria, y quizá encaja o va a encajar en otro orden (Gardea 2005: 3).

Yo me siento a escribir y me domina la sensación de que tengo que obedecer (1994b: 70).

Sin embargo, esto no hace más que generar francas problemáticas en torno al significado que tiene para un escritor de ficción su lenguaje. La preeminencia del lenguaje sobre la estructura, la confianza en la palabra y su resonancia, así como la espera, la contención y el silencio circundante son elementos de esa concepción de la escritura que, evidentemente, dejan huella en el lenguaje del autor, el cual se podría definir como aproximativo. Su ficción otro tanto resulta marcada por este mismo carácter que dota de ambigüedad a las historias y, por cierto, pone en crisis nociones de la narrativa convencional como el personaje y el argumento. Indudablemente, Gardea re-semantiza el gesto de una escritura hermética después de un siglo de narrativa moderna. Es un autor que ciertamente tiene puntos de contacto con una narrativa vanguardista (poca concesión al lector, la relevancia del proceso creativo, la subversión), pero que no se siente tentado a seguir el juego de las vanguardias históricas, juego que al final revela las contradicciones de una vanguardia ya muy institucionalizada que promete novedad. ${ }^{7}$ Más que sostener un diálogo con la literatura de vanguardia, la narrativa y el lenguaje de Gardea - a decir de su concepción de la escritura - parecen inspirarse en los discursos aproximativos de la mística y la ascética, que ciertamente son lenguajes transgresores.

Gardea emplea un lenguaje aproximativo que avanza por medio de imágenes y da cuenta de una expresión sugerida. Un lenguaje que, en cuanto narrativa, lo relaciona con la obra de ficción de José Lezama Lima, por quien profesaba admiración y reconocía su influencia: "Es para mí quizás el más grande novelista latinoamericano. Pienso en Paradiso y Oppiano Licario. Es un autor que releo. Yo creo que el espíritu de Lezama

\footnotetext{
${ }^{7}$ Julio Premat (2013, 2014 y 2016) realiza algunos cuestionamientos acerca del estado de la literatura contemporánea y su paulatino agotamiento que ayudan a situar la posición estética de un autor como Gardea.
} 
Lima me acompaña, no lo digo como pretensión, hablo del espíritu de su literatura. Creo que me ha ido permeando" (2009: 73). No es casual este reconocimiento por un autor que igualmente gustaba de emplear un lenguaje aproximativo y tenía profundo interés en la mística y la ascética. La noción de la "Sobreabundancia" que Lezama Lima formuló a lo largo de su obra es expresiva de esta manera de trabajar el lenguaje: "En palabras de Lezama Lima, estamos ante la Sobreabundancia. A ella solamente podremos aproximarnos por 'semejanzas', por 'imágenes', por 'paradojas'" (Xirau 1992: 36).

Justamente, sin demeritar la importancia de la elipsis y la dislocación sintáctica, la imagen poética en tanto analogía brinda mucho de su carácter al lenguaje aproximativo de Gardea. Mientras los otros dos recursos imponen un ritmo pausado e incluso especulativo en la narración, la imagen por medio de semejanzas va abriendo un abanico de significados en la historia. La naturaleza ambigua que muchas veces tienen las imágenes añade otro ingrediente importante a este lenguaje aproximativo. Ahora bien, la manera como el autor las hilvana en la narración en El diablo en el ojo es por medio de un desarrollo metafórico. Este recurso se remonta a Proust, quien con À la recherche du temps perdu abrió posibilidades narrativas a la imagen en tanto analogía. ${ }^{8}$ En la narrativa mexicana, tal recurso puede verse incipientemente con Efrén Hernández de la mano de la digresión. Por ejemplo, en Cerrazón sobre Nicomaco, el narrador brinda continuidad narrativa al desarrollo metafórico en torno a una araña

${ }^{8}$ La intervención de la imagen, como parte del desarrollo narrativo de À la recherche... y no como un mero elemento ornamental, fue vista por Albert Henry cuando al reconocer la complejidad de la metáfora hilada recordaba un pasaje del segundo tomo del ciclo. En éste, el narrador comienza a emprender una serie de paseos con Madame de Villeparisis y ve la imagen de un "arbóreo mozo". Al reparar en la capacidad de la metáfora hilada para evocar un paisaje intermitente o un personaje episódico, Henry observó que la serie metafórica del pasaje podía involucrarse en el nivel de conjunto de la obra al poseer una función estructural (cfr. Henry: 136-137); Luz Aurora Pimentel analizó este pasaje con detalle para destacar el aspecto narrativo de la metáfora hilada. Apreció en ella una dimensión "paranarrativa" originada a partir de la imagen del mozo arborescente: "In the metaphoric description of the footman, a virtual paranarrative line is traced, coexisting with the main diegetic space and time co-ordinates" ["En la descripción metafórica del mozo, se traza una línea paranarrativa virtual, que coexiste con el espacio diegético principal y las coordenadas del tiempo" (traducción propia)] (Pimentel: 73). 
(Hernández: 46-47). Se trata de un recurso que introduce un cambio de perspectiva en la narración. Hay un aparente alejamiento de los personajes para centrarse, en cambio, en objetos muchas veces nimios, pero cuyo desarrollo metafórico tiene un sentido en la historia que se cuenta.

El manejo de este recurso por Gardea en El diablo en el ojo, donde además lo agudiza y emplea con mayor profusión como ambigüedad, refleja una voluntad estilística más comprensible de acuerdo con la particular concepción escritural del autor.

\section{Un mundo pulsional}

Como ya se ha adelantado, El diablo en el ojo (México, Leega Literaria, 1989) es una de las novelas más ricas de Gardea tanto en procedimientos estilísticos como en su visión de mundo. Prácticamente agota el ciclo de aquellas novelas que se ambientan en el pueblo ficticio de Placeres. Por esta razón, representa uno de los momentos más logrados de la narrativa gardeana y, al mismo tiempo, un punto de inflexión importante hacia nuevos derroteros. Entre lo más destacado de la novela está un fondo pulsional en la historia. Para ello se examinan con detalle dos pasajes significativos de los primeros capítulos de la novela. Su elección obedece, principalmente, a que en éstos el autor practica un complejo desarrollo metafórico, en que se representa esa dimensión pulsional. En cada uno, se realiza un análisis estilístico de su construcción y se lo acompaña de una perspectiva psicoanalítica con las nociones freudianas de pulsión. ${ }^{9}$ Ello con el objetivo de aclarar en qué sentido se habla de una dimensión de pulsiones en la historia.

\footnotetext{
${ }^{9}$ Cabe aclarar que, dada la complejidad del lenguaje de Gardea y a fin de penetrar con más profundidad en su sentido, el análisis se restringe sólo a esos dos pasajes, por lo que no se ocupa del posterior desarrollo argumental y el desenlace. Ello se ha considerado necesario debido al propósito específico del presente artículo, además de que analizar algunos otros pasajes decisivos de la totalidad de la novela habría requerido un espacio mucho mayor. De ahí el sello estilístico de este análisis que intenta ser consecuente con la complejidad verbal de Gardea y dar cuenta de una obra con una riqueza enorme que bien merece mayores estudios.
} 
PULSIÓN DE VIDA: LA SEXUALIDAD

El diablo en el ojo inicia con el juego con una llave que el narrador trata de introducir en la cerradura de un cajón. Se trata de una manipulación que adquiere fuertes connotaciones sexuales, pero de una manera particular en el contexto de la historia. Supone una experiencia fantasmática por parte del narrador, esto es, una representación mental imaginaria que particularmente crea una ilusión de los sentidos. Tal fantasía sensorial empieza expresándose por medio de una ilación metafórica alrededor del fuego. Hay una serie de interacciones metafóricas en torno a este elemento, por medio de las cuales se desarrolla la narración:

Con la punta de la llave sentía la madera del cajón armado de chapa. Comenzaba a deslizar la punta a la derecha. Oía cómo iba abriendo un surco, en el campo de la tabla. En el polvo de los días. Se calentaba el cuerpecito de la llave. Me llegaba el calor a los dedos y la mano. No había modo de verlos, pero la punta y el polvo, debían encontrarse ardiendo. No paraba yo de labrar. Adrede el juego con la punta. La ponía a garabatear, a que hiciera del surco un bucle. Imaginaba mi ojo al rizado. En otra noche que no fuera la del animal nocturno, el rizado, resorte lleno de incandescencia, derritiendo en su luz el aire oscuro. Pero entonces, no. Entonces, el bucle a fuego, contenido por paredes que hervían, planchas de una estufa. Panecitos, se tostaban las motas de polvo. Aspiraba yo su olor y el de las invisibles Ilamas. La punta, luego, destruía el más denso de los dos olores; desmoronaba los panecitos, mezclaba el carbón de sus migas al resto del polvo. La muerte de uno de los olores, fortaleza, hasta el colmo, del otro (1989a: 6-7).

A partir de la analogía entre la llave y un arado, se suscita la imagen del fuego en la deixis de la narración. Tal imagen tiene un desarrollo sustancial, como se puede apreciar en el efecto que produce en el narrador, quien pasa del deleite lúdico con el fuego a respirar olores perniciosos, cuando el aroma a quemado supera al otro más grato de los "panecitos" calientes. Realmente, tal efecto del fuego llega a amenazar al narrador, por lo que tiene que detener el juego con la llave: "Como vapores de un ácido, me estaba quemando el tufo la nariz. Había que enfriar el corazón del fuego. [...] Entraban mi mano y la llave en reposo. Mantenía la llave pegada a la madera" (7). 
Como parte del juego imaginario y la ambigüedad de las imágenes, cabe advertir que el narrador manifiesta tener conciencia tanto del animismo fantasioso de la llave como de la condición imaginaria del fuego; es decir, al principio de la narración, tales fenómenos corresponden a algún plano de irrealidad de la historia o al parecer a cierta realidad psíquica, a diferencia de lo que ocurrirá después. Igualmente, hay que mencionar que, tras esta fantasía sensorial, el narrador da cuenta de algo que proviene del exterior: el ruido de una planta de luz que fuerza un personaje identificado como Boscán.

Más adelante, el narrador emprende de nuevo el juego con la llave. Prosigue con las imágenes alrededor del fuego, ahora por medio de otro tipo de ilación metafórica: la llave-un brasero:

Conducía yo el metal como si lo llevara en un brasero copeteado de carbones. Desgajarse uno de la montañita y caer al suelo, en un abrir y cerrar de ojo, el incendio del campo. El corazón del fuego, trasladado, desde su centro en la llave, a mi persona. Los centros son ordenadores. Desdeñosos también. Pero yo no me encastillaba sino que, como un cristal vigoroso, señalaba a las llamas que me envolvían su dirección. Mis órdenes, una especie de viento, les arrancaban chispas. Las chispas volando, entreverando sus colas de cometa, tejían una red luminosa (8-9).

Hay aquí un momento de ambigüedad. La posición del narrador, el cual se había mantenido consciente del aspecto ilusorio del juego con la Ilave, se modificará a partir de ahora, cuando éste aluda a una escisión bastante ambigua entre lo que se imagina y la experiencia concreta con la mano que manipula la llave: "Pero mi mano nada participaba en lo imaginario. Había continuado con lo suyo" (9). El narrador parece reconocer que, en el fondo, no experimenta una especie de realidad psíquica sino una realidad que se podría calificar de material, apelando a una perspectiva psicoanalítica. Sin embargo, no es propiamente él quien la experimenta como su mano, la cual adquiere un rango de mayor protagonismo en la narración. Es como si ésta estuviera separada del narrador y siguiera sus propias motivaciones.

Tal escisión entre el narrador y su mano se correlaciona de alguna manera con la que existe entre lo imaginado y lo real. Ocurre una fractura en la fantasía sensorial del juego con la llave, que devuelve al narrador a la 
realidad material. Pero esta vuelta a lo concreto pronto será revertida de nuevo por la imaginación. Habrá, por lo tanto, un desvanecimiento mayor de los límites entre lo imaginario y lo real, cuando se revela una inusitada materialización de la imagen (ya no ilusoria) en la historia. La referencia a la mano no es gratuita en esta parte del relato, pues alude al sentido más concreto de todos en medio de una compleja elaboración imaginaria.

Comienza, entonces, un largo pasaje donde la penetración de la llave en la cerradura explicita todavía más las connotaciones sexuales. Por medio de la ilación metafórica (la llave-un perro, la cubierta de la chapa-una isla, el ojo de la cerradura-un reloj de arena, la yema del dedo índice-un topo), se suscita una especie de frotamiento que busca inflamar un objeto de deseo ausente. Se trata de uno de los pasajes más insólitos y ambiguos de la novela así como de los más reveladores para introducirse en su mundo ficcional. Paulatinamente, el juego imaginario con la llave va señalando un camino de sensaciones cada vez más alucinantes, en el sentido de que aquello que supone una realidad psíquica se materializa en la ficción. Se advierte un regodeo absoluto en el desarrollo narrativo de la metáfora: "Como hocico de topo, la yema husmeaba en el agujero. Había sentido los perfumes de sus paredes de madera, alcanzadas por el fuego de la entrada. La exaltación de la yema se comunicaba al resto del dedo y lo hacía endurecerse para embestir" (10).

Hay, naturalmente, una relación proporcional entre la experiencia cada vez más intensa del narrador con el juego con la llave y la manera de relatarla por medio de una progresión metafórica. Justo con la analogía entre la yema del dedo índice y un topo, se alcanza un mayor grado de fantasía sensorial:

Pero el agujero, taponeado, pronto saturaba de perfume su oscuridad. Su noche se convertía en un licor fuerte, en un convite a la embriaguez. Empezaba yema y dedo a perder los estribos. Gemía la yema, encorchada en el ojo. El empuje del dedo, también le arrancaba gemidos. La mano se había metido por su cuenta en el afán, como cuando la ponemos en carne de mujer (10-11).

Se observa un mayor desarrollo narrativo de la metáfora con la animalización del dedo índice, la intensificación del sentido olfativo y la experiencia que adquiere matices sexuales con la evocación del cuerpo feme- 
nino. Pero éste es apenas el comienzo de un par de ilaciones metafóricas más que llevan el juego imaginario con la llave a una culminación alucinante. Aquí es donde se constata la inexistente frontera de lo imaginario y lo real. Se reconoce, en cambio, un plano distinto de la experiencia en que las diferencias entre realidad psíquica y realidad material carecen de sentido. La una es la otra y viceversa: la experiencia cobra inusitada fuerza en cuanto lleva a lo imaginado a su materialización efectiva. La primera ilación metafórica es el instante-un globo, que se expande a tal punto que Ilega a contener en su interior hasta al propio narrador y los sonidos del exterior (tanto aquel ruido proveniente de una planta de luz como algunos otros que producen unos grillos, todo ello en medio de un Ilano, en franca alusión a Placeres):

Lapso insignificante. Pizca de polvo en la tolvanera del tiempo. Que iba a transcurrir a la velocidad normal, pensé; y no. La pizca, segundo a segundo, fue llenándose no sólo del ruido del motor de Boscán, sino de otros. Acompañantes, de grillos la mayoría. Entreverados. Parecida a qué veían los ojos de mi imaginación la pizca. Era un globo, pero yo me encontraba dentro, como estar en el aire del llano (11).

Más adelante, el frotamiento con la llave conduce la experiencia hasta un momento de clímax. El narrador se identifica con un "manojo de varas secas" por medio de otra ilación metafórica, cuyo desarrollo narrativo llega a su culminación cuando por fin introduce la llave en la cerradura. Tras esto, viene un relajamiento del narrador y el fin del juego imaginario con la llave:

Los dedos que maniobraban sentían arriba, en la cabeza de la llave, aumentar el calor de la que iban ensartando como una sonda. Pero el retumbar, también crecía; se hinchaba con más ruido el trueno. La violencia presente en el aire me agitaba como un manojo de varas secas el alma. Azotaba las varas. Silbaban en la oscuridad. Y era un milagro, centro yo del estruendo, el poderlas oír como las oía. Para menguar sus resonancias apliqué mi mano libre al pecho y metí, de un solo, brusco empujón, en el agujero, el resto de la llave. Yo no lo había buscado, imaginado, pero cuando la llave tocó fondo y mis dedos sintieron el fuego que consumía la laminilla, todo el escándalo de los ruidos, se acabó. Me apoyé en el mueble, y el mueble, como un animal en sueños, protestando, soltó un quejido (12). 
Se puede advertir las connotaciones sexuales en este juego imaginario con la llave. En particular, una suerte de onanismo dada la franca ausencia del objeto humano de deseo y, en cambio, la creación de una presencia fantasmática por un ser que se podría definir como introvertido. ${ }^{10}$ Toda esta fantasía sensorial con la llave representa ciertamente la experiencia de una vida fantasmática volcada hacia el interior. A decir por el texto, esta vida aparece marcada por la soledad, donde la presencia femenina sólo puede suscitarse afantasmada por medio de la elaboración imaginaria y desde la perspectiva exclusiva de la genitalidad (la hendidura). No sólo se trata de la soledad del narrador, sino de un estado de carencia exacerbada de esa otra parte.

Se cuenta con un indicio acerca de la personalidad del narrador, pero también a lo largo del juego con la llave hay asomos del mundo donde se ambienta la historia. Se había hablado de un personaje Ilamado Boscán, quien forzaba el motor de una planta de luz. Esta alusión mínima se desarrolla narrativamente en el siguiente capítulo. En éste se refiere cómo Boscán recibe una paliza por parte de Borja, el diablo, y su grupo de hombres debido a que ha perturbado el sueño del pueblo.

Cabe reparar en el sentido del juego con la llave, dada su relación con el fantasear del narrador, puesto que a partir de ello se origina la problematización de los límites entre lo imaginado y lo real. Se trata de una problemática que Sigmund Freud había identificado en el primer análisis de obra literaria que publicó, en la que el protagonista (un profesor de arqueología) fantasea sin descanso con la imagen de un bajorrelieve. A tal punto Ilega su fantasear que le fabula un nombre, un linaje, y eleva "la fantasía de la existencia y el sepultamiento de la doncella llamada Gradiva a la condición de un delirio que cobró influjo sobre sus actos" (1992a: 13). Sin duda, el fantasear del narrador de El diablo en el ojo es más inmediato y alucinante, pero el problema en cuanto a la realidad que adquiere lo fantaseado es el mismo. Ahora bien, el juego y el fantasear representan operaciones similares que delatan un elemento de enorme importancia.

\footnotetext{
${ }^{10}$ El fantasma sexual o presencia fantasmática alude a un objeto imaginario que, de acuerdo con Freud, es una formación de deseo creada por el ser introvertido, quien se aparta de la realidad y se vuelve, en cambio, hacia esa vida fantasmática. "Introversión" en Laplanche y Pontalis 2004.
} 
Habría que situar en contexto el juego con la llave para indagar en ello. Se tiene un narrador caracterizado por la soledad circundante y una vida interior afantasmada; pero, más aún, lo caracteriza una base anímica que apunta hacia el deseo insatisfecho y las fuerzas pulsionales de la fantasía. ${ }^{11}$ Este fondo pulsional parece estar detrás de toda la elaboración imaginaria entretejida en el juego con la llave.

Es peculiar cómo se narra el juego imaginario con la llave y la cerradura pues evidencia esa dimensión de pulsiones. Se trata de una narración por medio de imágenes que reflejan, en el fondo, la simbolización de la genitalidad masculina y femenina: el arado y el surco en un inicio, seguidos de una complicada sucesión de imágenes por las que discurre la narración. En estos términos, se puede hablar de la representación de una realidad pulsional en la historia. Dado el relativo desdibujamiento del personajenarrador en un sentido convencional, las imágenes adquieren perfiles más visibles en la narración y sólo por éstas es posible inferir el juego imaginario del narrador con la llave.

Cabe considerar el concepto de pulsión, ya que por medio de esta noción se explica mucho de lo subyacente en lo narrado. De acuerdo con Freud: "la 'pulsión' [...] aparece como un concepto fronterizo entre lo anímico y lo somático, como un representante [Repräsentant] psíquico de los estímulos que provienen del interior del cuerpo y alcanzan el alma, como una medida de la exigencia de trabajo que es impuesta a lo anímico a consecuencia de su trabazón con lo corporal" (1992c: 117). Hay en el concepto una zona de ambigüedad entre lo psíquico y lo somático que, trasladado a lo narrado, se refleja en la problemática entre lo imaginario y lo real, las realidades psíquica y material, que se manifiesta a lo largo del juego con la llave. Pero al final, ha ocurrido que tales distinciones pierden sentido y se fusionan con la materialización de la imagen en la historia, una operación producto de la más viva fantasía sensorial del narrador y la exacerbación de su deseo insatisfecho. Vale apuntar que tales fenóme-

\footnotetext{
${ }^{11}$ En otro texto donde Freud se ocupó de los problemas de la creación literaria, centró su interés en el examen de las fantasías en las que reconoció el orden de lo pulsional: "Deseos insatisfechos son las fuerzas pulsionales de las fantasías, y cada fantasía singular es un cumplimiento de deseo, una rectificación de la insatisfactoria realidad" (1992b: 129-130).
} 
nos de materialización de la imagen se darán por hecho, sin perplejidad alguna del narrador, en el resto de la novela. Con ello desde este primer capítulo, el narrador parece señalar ciertas condiciones específicas de su mundo ficcional con vistas a establecer un pacto con el lector.

En este punto, habría que señalar solamente que el narrador parece satisfacer su deseo, en cuanto a que "el logro del placer del órgano" (Freud 1992c: 121) es la meta a la que aspira la pulsión sexual, la cual está en juego en el relato para distinguirla de la pulsión de autoconservación que también aparece en el texto freudiano. Sin embargo, no habría que perder de vista que se trata de una experiencia onanista, carente del otro y creadora de su propio fantasma sexual, como una forma de amar en un mundo con muy pocas expectativas afectivas.

\section{PULSIÓN DE MUERTE: LA VIOLENCIA}

Tal como se desarrolla posteriormente la alusión a Boscán, el disturbio provocado por la ruidosa planta de luz que éste fuerza durante la madrugada le amerita una tremenda paliza por parte de Borja y sus hombres. Esto se narra en el segundo capítulo de la novela cuando éstos irrumpen en el patio de Boscán para cercarlo y destrozarle algunas pertenencias. La violencia será una constante de la novela. Si bien es sistemática e incluso metódica como se aprecia en el ataque a Boscán, también responde a un fondo instintivo y pulsional. Esto se puede observar más claramente en el tercer capítulo, cuando Borja hiere a uno de sus hombres y exhibe su grado de odio y abuso de fuerza, desde una zona insondable de la naturaleza humana. Sobre todo, por el carácter de violencia latente que se visibiliza en el fondo del personaje.

Como en el pasaje correspondiente a la pulsión de vida, el pasaje que merece analizarse con detalle conlleva un sugerente y ambiguo desarrollo metafórico. Éste ocurre cuando el grupo de Borja se encuentra reunido en una habitación y estiman segura la muerte de Boscán, aparte de idear algún negocio absurdo como la confección de flores de papel, que propone uno de los hombres del grupo: Meneses. En este contexto, prácticamente de la nada, al tocar apenas éste el hombro de Borja, se desencadena una brusca reacción en contra de Meneses. El narrador jamás la describe ex- 
plícitamente sino, más bien, se ocupa de las consecuencias de la súbita reacción de Borja tan intempestiva como encolerizada:

La mano atrevida ardía. Meneses la sacudía como si trajera prendido un perro; la azotaba contra el aire. Meneses, agitado, alumbrado por las Ilamas, danzaba. La antorcha que él desmelenaba recalentaba, como un sol de verano, el aire de los espectadores. Las respiraciones. Borja, próximo a su ventana, paliaba lo sofocante con bocanadas de aire fresco. Comenzaron envidias, por aquel poro de alivio, de los arrinconados. Arana, igual que un sediento en el infierno, veía azules las bocanadas. Pero ni él, ni los demás, tan valientes como para atravesar, o bordear, la zona donde era alimentado por el danzante fuego. Grande fortuna la de Meneses; no es la mano el pecho, la cabeza. Meneses un cerillo. Alcanzado por la lumbre, el neutral, Arana, Ilamarada intensa. De pajonales. Abrasarse un taniche de tablas. Arana volteó atrás como esperando encontrar, en un callejón sin salida, otra ventana. La luz del fuego iluminaba la cal de las paredes, les echaba sombras. Distinguía la suya Arana, en la juntura de las paredes. Larga y atormentada, se pegaba a la juntura como a una grieta abierta al aire de la calle. En el estómago de Arana, el filo, el doloroso frenesí de su sombra. Las demás sombras, escalonadas, la miraban agonizar. Los perfiles, temblones. No quiso seguir viendo Arana; se volvió a Meneses. El propósito, hallar, en el tupido enmarañado que dibujaba la antorcha, escape (28-29).

Se advierte la continuidad de la metáfora herida-llamarada en la mano de Meneses y, de nuevo, la aparición de imágenes poéticas en torno al fuego. La relativa realidad que la metáfora adquiere en la deixis de la narración motiva la acción de los personajes. En este caso, la herida-llamarada se convierte en una fuente de calor que inunda el cuarto donde están los personajes e impone un respeto al fuego, lo que se puede interpretar como temor hacia la acción de Borja. Esto se puede ver en el comportamiento de los personajes ante la situación. Mientras Borja aminora el calor con el aire de la ventana, los demás ambicionan ese aire fresco. Sin embargo, para acceder a éste, el resto tiene que pasar cerca de Meneses y arriesgarse a ser "alcanzado por la lumbre", de acuerdo con la dimensión imaginaria que la metáfora ha abierto; como arriesgarse a ser blanco de la violencia instintiva de Borja. Justamente, el desarrollo de la analogía heridaIlamarada todavía provoca el abrasamiento de Arana y la proyección de su sombra en las paredes del cuarto. Se redondea con ello la ambientación infernal aludida anteriormente: Arana, igual que un sediento en el infierno. 
Esto resulta expresivo de una dimensión hasta ahora latente en la historia y que emerge con toda su crudeza.

Tal alusión al infierno se materializa en la historia con la particular caracterización de los personajes detonada por la metáfora. Los personajes se hallan en la habitación envueltos por el intenso calor, pero sobre todo se mueven como condenados. Se los caracteriza como seres sufrientes y degradados por medio de la imagen de sus sombras pegadas a las paredes del cuarto. La voz narrativa enfatiza este aspecto de los personajes: sus sombras son largas, atormentadas, están escalonadas y tiemblan. Encerrados en el calor como en el temor y la violencia circundante, los personajes así descritos habitan un espacio verdaderamente infernal.

El desarrollo de la metáfora herida-Ilamarada se continúa algunas líneas más adelante, después de que Arana marca el rumbo hacia Borja para ir con él y, de algún modo, respaldar su fechoría; en tanto que otro personaje de nombre Orive se opone y, en cambio, busca el apoyo de los demás para Meneses:

La ardiente, como sumergida de pronto en agua, se apagaba. Dejó de girar el danzante. Su pobre mano humeaba.

La acunaba en la otra, mirándola pálido. En el mero centro del piso de nadie Meneses parecía contemplar un muñón en flor. La cuna empezó a gotear como techo viejo. Las gotas humedecían el silencio templado por el fuego; lo perforaban, hacían de él coladera. Borja las ignoraba; desde su lado, no se veían. Ninguno, tampoco, podía escucharlas (30).

En este caso, el desarrollo metafórico llega a su culminación, donde no se expresa más metaforización alrededor del fuego sino su contraste: el agua y la humedad que lo han sofocado. Se detiene la herida de Meneses, pero queda su cicatriz en tanto marca representativa de la maldad de Borja. Más adelante, su presencia perniciosa de nuevo se manifiesta por medio de otro desarrollo metafórico con la luz de su navaja amenazadora. Esto ocurre cuando dos miembros del grupo, Arana y Orive, intentan escarmentar a Borja por atacar a Meneses. Orive es quien se dirige a bloquearle la retirada, pero de nuevo una súbita reacción de Borja se impone. En este caso, se trata de una metaforización en varias direcciones y no relacionada únicamente con un solo punto de comparación: 
Como rasgar una seda, tronchada al deslumbramiento; desguarnecido, Borja reaccionaba. Con el blanco gallito pendenciero de su navaja en la diestra, firme, le marcaba el alto a Orive. Partida la copia como una esfera, la luz retornaba a Borja y le encendía, en el pico del animal, un sol. Crepusculares de miedo por lo que estaban presenciando Arana, su gente, no encontraron respuesta al violento, ya en franco son de pelea.

Fue Orive, el sangre fría. Sus palabras, hubo acuerdo en ello en aquel mundo a la sombra, no para Borja. Habló con el sol, lucimiento del arma. Le dijo cosas como si razonara con un ubar a su merced, huérfano de telaraña. El patón se equilibraba con harta dificultad en la punta de la hoja. Orive no paraba de acosarlo. Le hizo ver la tristeza de su destino. Moriría reventado. La mano de Borja, la de Dios. Y Orive le aconsejaba apearse del mortal incómodo sillón, antes del movimiento fatal. Las palabras del que no había siquiera pestañeado al aparecer la navaja en el aire, le estaban sonando a Borja a lengua de loco. Trastornados del juicio por haber visto correr sangre. De esos, Orive. Pero Borja miraba de soslayo el arma. Demasiado resplandor. De veras un sol, una pancita de luz el brillo, pensó. Miedo al contagio de la demencia del otro. Guardaba la hoja. La regresaba a la bolsa del pantalón. La luz, como el agua del mar. Volvía a menearse. [...] Tambor la manta del cielo del cuarto, en la orden, perentoria, sostenida por un filo y una punta escondidos. Orive y compañía debían desalojar de inmediato (35-36).

El desarrollo metafórico crea una red de asociaciones a partir de la navaja de Borja. Ésta toma una apariencia deslumbrante: un gallo de pelea cuyo pico se enciende con intensidad como expresión de peligro. Pero también este filo refulgente adquiere la fisonomía de una araña amenazadora como vacilante con la que razona Orive. Ambas analogías poseen consistente continuidad argumental pues expresan, por una parte, la inminente y brutal reacción de Borja, y por otra, la espinosa mediación ante ésta. Al final, la última imagen de este desarrollo expresa la distensión del conflicto pero, al mismo tiempo, la amenaza que se mantiene latente. La asociación sutil de la navaja de agua de mar a filo escondido que apenas sostiene la tormenta deja todavía bastante cargado de tensión el ambiente.

El estado de inminente violencia permanece hasta que el grupo de Borja logra salir de la habitación. La agresividad de este personaje es decisiva a lo largo de la novela. Tal como es representada, resulta un elemento que merece relacionarse con un fondo instintivo y pulsional, aunque en un orden distinto al del pasaje del juego con la llave. En este punto cabe 
de nuevo apoyarse en Freud, quien elaboró una compleja teoría de las pulsiones a lo largo de los años. Tras formular la pulsión sexual y de autoconservación, éste introdujo la noción de pulsión de muerte en "Más allá del principio del placer" (1920), con lo que dio un giro tan significativo como controvertido en su teoría. Contrapuso a las pulsiones de vida (sexual y de auto-conservación) un nuevo tipo de pulsión más elemental en el desarrollo del organismo. Ya en "Lo ominoso" (1919) había advertido una naturaleza pulsional en el fenómeno de la repetición, que podía ser más fuerte incluso que el principio del placer y lindar con el Mal: "En lo inconsciente anímico, en efecto, se discierne el imperio de una compulsión de repetición que probablemente depende, a su vez, de la naturaleza más íntima de las pulsiones; tiene suficiente poder para doblegar al principio del placer, confiere carácter demoníaco a ciertos aspectos de la vida anímica" (1992d: 238). De modo que con la compulsión de repetición, concepto central en "Más allá del principio del placer", Freud examinó una formulación de la pulsión de muerte. Si bien lo hizo en este texto con una perspectiva especulativa, ${ }^{12}$ iría reafirmando esta noción con gran complejidad hasta el final de su obra.

La representación de la agresividad y aun la presencia diabólica de Borja en la novela de Gardea permite hablar de una pulsión de muerte en la narración. En específico, de una pulsión agresiva o destructora que se dirige hacia el exterior. De manera parecida a la pulsión sexual presente en el juego con la llave, la pulsión agresiva desencadena una compleja elaboración imaginaria. Ésta se manifiesta en torno a la herida de Meneses y la navaja de Borja con metáforas de fuego, luz y fauna en términos generales. A diferencia del pasaje del juego con la llave, en éste el narrador no expresa perplejidad alguna ante la materialización de la imagen.

\footnotetext{
${ }^{12}$ Resulta estimulante la manera como Freud reconoce estar pisando terreno virgen $y$, al mismo tiempo, declara un interés muy genuino; sin dejar de tener muy presente en adelante la alusión al advocatus diaboli: "Podría preguntárseme si yo mismo estoy convencido de las hipótesis desarrolladas aquí, y hasta dónde lo estoy. Mi respuesta sería: ni yo mismo estoy convencido, ni pido a los demás que crean en ellas. Me parece que nada tiene que hacer aquí el factor afectivo del convencimiento. Es plenamente lícito entregarse a una argumentación, perseguirla hasta donde lleve, sólo por curiosidad científica o, si se quiere, como un advocatus diaboli que no por eso ha entregado su alma al diablo" (1992e: 57).
} 
Tampoco su fantasía sensorial es motivada por el deseo insatisfecho sino, como se trata de explicar, por la agresividad de Borja desde una dimensión pulsional. Su representación se corresponde cabalmente con una narración que discurre mediante imágenes, cuya materialización expone tanto una elaboración imaginaria como efectivamente una intensa experiencia sensible. Esto es, de nuevo una fantasía sensorial tras la que palpitan profundas realidades anímicas.

De este modo, la materialización de las imágenes en el pasaje revela una poderosa fuerza de evocación de la dimensión pulsional. Vale observar que la viveza de las metáforas del fuego, la luz y los animales amenazadores se correlaciona con cierto animismo. En este punto, interesa entender esta actividad animista como una manifestación ominosa. Justamente en "Lo ominoso", Freud se pronuncia al respecto en la ficción literaria. ${ }^{13}$ De este modo, convenido el pacto con el narrador por el que la materialización de la imagen se da por hecho, la fantasía sensorial en el pasaje devela fuerzas secretas y amenazadoras. Es un proceso que delata la objetivación de temores muy arraigados, que para Freud se ocultan en el inconsciente y son reprimidos. En la novela, se puede apreciar que opera un animismo primitivo que instaura una realidad poderosamente emanada de pulsiones agresivas. El fuego, la luz, el gallo y la araña, bajo una apariencia perniciosa, abren una dimensión tanto psíquica como materialmente vívida de la reacción casi diabólica de Borja.

Por último, cabría poner énfasis en el talante de este personaje y el ambiente infernal que suscita en relación con la pulsión de muerte (agresiva). El carácter diabólico de Borja se hace patente al final del pasaje cuando éste todavía amaga a Orive en su huida, quien se había atrevido a encararlo:

13 Éste reconoce un examen aparte de lo ominoso en la ficción, donde encuentra un alcance mayor de sus efectos en comparación con la vida real. Pero también admite que, cuando el autor se sitúa en apariencia en el terreno de la realidad cotidiana, "entonces acepta todas las condiciones para la génesis del sentimiento ominoso válidas en el vivenciar, y todo cuanto en la vida provoca ese efecto lo produce asimismo en la creación literaria [...] haciendo que ocurran cosas que no se experimentarían —o sólo muy raramente - en la realidad efectiva. En alguna medida nos descubre entonces en nuestras supersticiones, que creíamos superadas" (Freud 1992d: 249-250). 
Como a un puñado de basurita, Borja dejó volar de su mano al enemigo. Pero luego, su arma le cortaba la retirada a Orive. Saltaba Orive como luz con el espanto de una sombra. De sonrisa amigable, Borja cerraba la navaja.

-Orive, usted y yo hemos sido, esta mañana, los verdaderos hombres.

-Usted, no. Hirió a Meneses.

Borja guardaba la navaja.

—Un diablo — dijo.

Orive le miraba, punzante, a los ojos. Pero en la hondura nada veía Orive (40-41).

En el breve y enigmático diálogo, Borja atribuye el ataque a Meneses a una influencia maligna. Lo demoniaco había sido aludido con la ambientación infernal de la habitación, donde el grupo se encontraba sometido al calor producido por la herida de Meneses. Pero con la misteriosa afirmación de Borja lo diabólico adquiere otra arista más allá de lo meramente infernal. Hay en este punto una correspondencia con un sentido muy especial de la pulsión de muerte desarrollado por Freud: el carácter demoniaco de la compulsión de repetición. ${ }^{14}$ Esto es, la repetición actúa sobre el sujeto de manera omnipresente e inevitable, aun más fuerte que el principio del placer. Es resentida como proveniente del exterior, y también es automática e incomprensible. ${ }^{15}$ Parecería quizá forzado trasladar estas nociones al texto de Gardea, si no fuera solamente para recalcar la representación de la violencia de Borja así como el sentido de lo diabólico en la historia, desde un nivel eminentemente pulsional. Por una parte, está el carácter latente de la agresividad de este personaje, proveniente de algún fondo insondable, que se representa por medio de una narración que jamás explicita el ataque concreto de Borja. Al contrario, de pronto nos hallamos en medio de una proliferación metafórica que expresa, en tanto fantasía sensorial, una realidad anímica hasta ese momento oculta.

\footnotetext{
${ }^{14}$ Desde "Lo ominoso" con la compulsión de repetición, se atisba un camino hacia la exploración de la naturaleza del Mal, determinante en "Más allá del principio del placer": "Las exteriorizaciones de una compulsión de repetición que hemos descrito en las tempranas actividades de la vida anímica infantil, así como en las vivencias de la cura psicoanalítica, muestran en alto grado un carácter pulsional y, donde se encuentran en oposición al principio de placer, demoníaco" (Freud 1992e: 35).

${ }^{15}$ La discusión sobre el aspecto diabólico de la pulsión de muerte en Freud ha sido detalladamente examinado por Louise de Urtubey en el capítulo "Le diable et la mort" de Freud et le diable.
} 
Por otra, está la condición imperiosa, casi automática e inexplicable de la reacción de Borja contra uno de los suyos: el diablo suelto.

\section{La ambigüedad de la imagen}

Por medio de este tipo de desarrollos metafóricos como los analizados se penetra en la naturaleza ambigua de la imagen y la visión de mundo de El diablo en el ojo. Tal visión se asienta en un terreno de pulsiones bajo el dominio de fuerzas instintivas e inaprehensibles. No por nada la forma en que se representa esa dimensión pulsional es por medio de la imagen y su desarrollo metafórico, como la simbolización de una realidad profunda: la genitalidad. Imposible negar que en la imagen hay un fondo de significado, que en varios casos descansa en estructuras antropológicas o en el imaginario. La imagen por excelencia es poseedora de una poderosa fuerza de evocación. Mircea Eliade, desde la perspectiva antropológica, afirmaba que "la misión y el poder de las Imágenes es hacer ver todo cuanto permanece refractario al concepto" (20). Hay algo que la imagen, próxima al símbolo, alcanza a revelar de lo profundo y lo inaprehensible, con toda su ambigüedad inherente. Así es la expresión del deseo insatisfecho como la revelación de fuerzas secretas y amenazantes.

El dominio de las pulsiones en la novela es fielmente representado por desarrollos metafóricos, los cuales revelan complejas elaboraciones imaginarias y hondas realidades anímicas. Se visibiliza con ello una zona de ambigüedad entre lo imaginario y lo real. Una realidad diferente en que al mismo tiempo se conjuga lo anímico y lo sensorial en una materialización de lo psíquico. La cualidad ambivalente de la imagen para revelarnos esta realidad es la piedra de toque de la visión de mundo de la obra. En ella lo volitivo se materializa, de modo que la fantasía adquiere sustancia para bien o para mal, ya sea el fuego sexualizado del juego con la llave o el fuego amenazador de la herida de Meneses. En todo caso, en el contexto sombrío de Placeres, esta materialización representa una completa fantasmagoría a la vez esperanzadora y ominosa.

Ahora bien, con las nociones de pulsión diferenciadas de Freud se repara en los sentidos encontrados a los que apuntan los desarrollos metafóricos. La sexualidad y la violencia presente en El diablo en el ojo son 
rumbos que cabe distinguir también en términos de pulsión de vida y de muerte. Esta síntesis freudiana de la pulsión que se puede advertir en los primeros desarrollos metafóricos de la novela expresa en esencia su conflicto medular: la lucha incesante entre la luz y las tinieblas, el diablo y el ojo. Representa el contraste dramático de la novela, cifrado en anhelos que buscan encarnar o apariciones ominosas. Empero, no deja de ser significativo que la expresión de estas valencias encontradas sea por medio de imágenes ambiguas y complejos desarrollos metafóricos. Como si se tratara de pulsiones del lenguaje que van tomando forma y estructuran la historia. Así, en medio de la densidad de los pasajes analizados también se van dando rápidos indicios que se desarrollan después. Hay atisbos al exterior (Boscán, la planta de luz, Placeres) que permiten al lector ir abriéndose paso en la historia, quizá, para experimentar algo de la oscuridad textual de la novela. De ahí el papel decisivo del ojo como narrador, que relata la historia de una venganza entre claroscuros de un mundo sombrío. Fiel a una concepción de la escritura, Gardea ha ensayado en El diablo en el ojo un modo de narrar excepcional.

\section{Bibliografía}

ANDRÉs, RAMÓN. No sufrir compañía. Escritos místicos sobre el silencio. Barcelona: Acantilado, 2010.

Eliade, MiRCEA. Imágenes y símbolos. Madrid: Taurus, 1992.

Freud, Sigmund. "El delirio y los sueños en la 'Gradiva' de W. Jensen" [1906], en Obras completas, t. 9. José L. Etcheverry (trad.). Buenos Aires: Amorrortu, 1992a. 1-79.

Freud, Sigmund. "El creador literario y el fantaseo" [1907], en Obras completas, t. 9. José L. Etcheverry (trad.). Buenos Aires: Amorrortu, 1992b. 123-135.

Freud, Sigmund. "Pulsiones y destinos de pulsión" [1915], en Obras completas, t. 14. José L. Etcheverry (trad.). Buenos Aires: Amorrortu, 1992c. 105-134.

Freud, Sigmund. "Lo ominoso" [1919], en Obras completas, t. 17. José L. Etcheverry (trad.). Buenos Aires: Amorrortu, 1992d. 215-251.

Freud, Sigmund. "Más allá del principio del placer" [1920], en Obras completas, t. 18. José L. Etcheverry (trad.). Buenos Aires: Amorrortu, 1992e. 1-62.

Gardea, Jesús. El diablo en el ojo. México: Leega Literaria, 1989a.

GardeA, Jesús. "Trato de cascar las palabras como las nueces: Jesús Gardea". Entrevista de Araceli Hernández, en La Jornada (5 de septiembre de 1989b): 20.

GardeA, Jesús. "El mundo de los grupos literarios me atrae muy poco". Entrevista de Verónica Ladrón de Guevara, en El Financiero (14 de enero de 1993a): 57.

Gardea, Jesús. "Jesús Gardea: Producirse a sí mismo y desde sí mismo III". Entrevista de Agustín Ramos, en El Financiero (11 de mayo de 1993b): 63. 
Gardea, Jesús. "El afán del lenguaje". Entrevista de Miguel Ángel Quemain, en Tierra Adentro, núm. 71 (1994a): 5-9.

GardeA, Jesús. "Fustiga el narrador Jesús Gardea, 'El ogro de las rosas', a los escritores que usan la literatura para conseguir fama y poder". Entrevista de José Alberto Castro, en Proceso (17 de octubre de 1994b): 70.

GARDEA, Jesús. "'Escribir es un oficio donde tiene mucho juego la esperanza': Jesús Gardea, autor de Difícil de atrapar". Entrevista de César Güemes, en El Financiero (27 de septiembre de 1995): 67.

GardeA, Jesús. "La literatura: tráfico entre vivos y muertos". Entrevista de Vicente Francisco Torres, en Siempre! (6 de abril de 2000): 64-65.

GardeA, Jesús. "El Ilamado de Jesús Gardea". Entrevista de Daniela Tarazona y Joan Puig, en El Ángel de Reforma (13 de marzo de 2005): 3.

GardeA, Jesús. "La palabra es el cuento", en Lauro Zavala (ed.). Teorías del cuento III. Poéticas de la brevedad. México: Universidad Nacional Autónoma de México, 2008. 213-218.

GardeA, Jesús. "Jesús Gardea: Ananké". Entrevista de Daniela Tarazona, en El poeta y su trabajo. Universidad Iberoamericana, 32 (2009): 71-76.

Henry, Albert. Métonymie et métaphore. Paris: Klincksieck, 1971.

Hernández, Efrén. Cerrazón sobre Nicomaco. México: Universidad Nacional Autónoma de México, 2012. Libro electrónico disponible en: <http://www.lanovelacorta.com/cerrazon/index.html>.

Laplanche, Jean y Jean-Bertrand Pontalis. Diccionario de psicoanálisis. Dir. Daniel Lagache. Buenos Aires: Paidós, 2004.

Pimentel, Luz Aurora. Metaphoric Narration. Paranarrative Dimensions in À la recherche du temps perdu. Toronto: Toronto University Press, 1990.

Premat, Julio. "Los relatos de la vanguardia o el retorno de lo nuevo", en Cuadernos de Literatura. Universidad Javeriana, 17 (2013): 47-64.

Premat, Julio. "Contratiempos. Literatura y época", en Revista de Estudios Hispánicos. Universidad de Puerto Rico, 48 (2014): 201-217.

Premat, Julio. "Fin de los tiempos, comienzos de la literatura", en Eidos. Universidad del Norte, 24 (2016): 104-126.

Poe, Edgar Allan. El cuervo [The raven]. Seguida de la Filosofía de la composición. México: El Colegio Nacional / Tucán de Virginia, 1998.

TORRES, Vicente Francisco. "Un maestro del desierto y del estilo", en Tema y Variaciones sobre Literatura. Universidad Autónoma Metropolitana-Azcapotzalco, 38 (2012): 141-159.

URTUBEY, LOUISE DE. Freud et le diable. Paris: Presses Universitaires de France, 1983.

XIRAu, Ramón. Palabra y silencio. México: Siglo XXI, 1968.

XIRAu, Ramón. De mística, México: Joaquín Mortiz, 1992. 
DANIEl SAMPERIO JIMÉNEZ

Doctor en Literatura Hispánica por El Colegio de México. Becario Conacyt, actualmente realiza una estancia posdoctoral en la Universidad Autónoma MetropolitanaAzcapotzalco. Sus líneas de investigación son la narrativa moderna y contemporánea así como la poesía del siglo xx. Entre sus publicaciones principales están: "Ficción, historia y mito en El río sin orillas de Juan José Saer", Valenciana, 21 (2018): 27-41; "Cascar las palabras como las nueces: formación y escritura en Jesús Gardea", Revista de Literatura Mexicana Contemporánea, 72 (2017): 5569; "Algunos puntos de partida de Compañeros de viaje: la lectura de Cántico en Jaime Gil de Biedma", Philobiblion. Revista de Literaturas Hispánicas, 5 (2017): 43-58. 